\title{
The plankton from Maracajaú reef ecosystem (Brazil) - offshore coral reefs under multiple human stressors
}

\author{
S. Neumann-Leitão ${ }^{1}$, F. A. N. Feitosa ${ }^{1}$, E. Mayal ${ }^{2}$, \\ R. Schwamborn ${ }^{2}$, M. G. G. Silva-Cunha ${ }^{1}$, T. A. Silva ${ }^{3}$, \\ N. F. Melo ${ }^{4} \&$ F. F. Porto Neto ${ }^{5}$ \\ ${ }^{I}$ Department of Oceanography, Federal University of Pernambuco, \\ Brazil \\ ${ }^{2}$ Department of Zoology, Federal University of Pernambuco, Brazil \\ ${ }^{3}$ Department of Education, Bahia State University, Brazil \\ ${ }^{4}$ Department of Fishery Engineering, Federal Rural University of Pará, \\ Brazil \\ ${ }^{5}$ Department of Zootecny, Federal Rural University of Pernambuco, \\ Brazil
}

\begin{abstract}
To evaluate the Maracajaú reef ecosystem (Northeastern Brazil), observations, sampling and measurements were performed monthly during spring low tides from February to June 2000, covering the transition from dry to rainy season. In this area, there is an extensive (approximately $10 \mathrm{~km} \mathrm{x} 4 \mathrm{~km}$ ), but to date poorly investigated, offshore coral reef formation, where a Marine Protected Area was established recently. The reef area presented chlorophyll $a$ concentrations varying from $1.1 \mathrm{mg} \mathrm{m}^{-3}$ to $9.3 \mathrm{mg} \mathrm{m}^{-3}$, with higher values registered during the rainy season. Average zooplankton biomass values were $117.0 \mathrm{mg} \mathrm{m}^{-3}$ (microzooplankton) and $15.7 \mathrm{mg} \mathrm{m}^{-3}$ (mesozooplankton). A total of 136 phytoplankton taxa were identified. Diatoms were the most abundant and diverse group, with 102 species. Average phytoplankton density was $3,12510^{-3}$ cells $1^{-1}$. It was identified that there were 61 zooplankton taxa, with copepods showing the highest diversity ( 23 species) and abundance. Seasonal forcing determined the micro- and mesozooplankton community structure, rather than the coastal-offshore gradient. In spite of the distance from the coast (5 to $7 \mathrm{~km}$ offshore), this area is intensively used by local populations, mainly for artisan fishery and diving tourism. The area is exposed to seasonally varying negative impacts due to freshwater runoff, mangrove degradation and tourism, being also menaced by coastal eutrophication.
\end{abstract}

Keywords: reefs, hydrology, plankton, human impacts. 


\section{Introduction}

Reefs constitute the very foundation of immensely complex marine coastal communities of fundamental value and are among the most productive marine ecosystems [1]. Although geographically restricted to tropical seas and occupying only $0.1 \%$ of the earth's surface, coral reefs have globally important implications for marine biodiversity. Reefs support unusually diverse flora and fauna communities with distinctive taxonomic structure and geographical distribution patterns [2]. All reefs in which corals grow or grew in Northeastern Brazil, have a base of sandstone or sometimes another rock type cropping out of the sea floor. Where corals occur, there is also a great influence of algae which may grow at the seaward side of the reef, where the wave action is strongest [3]. Although the reefs do not completely consist of corals, they have important roles in protecting many low-lying shores from erosion, supporting fisheries, fostering tourism, and as sources of items for the souvenir and aquarium trades and of building material.

The reef plankton forms a specific community, which differs from the plankton communities of the surrounding pelagic areas of the open ocean in its species composition, in its behavior and in its abundance [4-6]. The plankton is a very important community to the reef fauna trophic web. Many organisms of the reef community other than corals are active and passive filter-feeders, which concentrate plankton and particulate organic matter.

The Maracajaú reef is a "table type", formed by numerous pinnacles like mushroom. The reef is almost constituted by calcareous algae, corals and vermetids. Thus, it is hypothesized that much of the plankton in waters immediately adjacent to these reefs comes from the reef itself. There are few studies in the Maracajaú area. Laborel [7] was the first who mentioned coral occurrence besides other fauna and flora in this area. Mayal et al. [8] presented the results of studies about five coral species in the area, Melo et al. [9] studied the zooplankton and Feitosa et al. [10] the reef ichthyofauna.

The present paper contributes to the knowledge of the diversity and biomass of the reef plankton occurring in Maracajaú. These reefs are very important to the artisanal fisheries and for the diving tourism.

\section{Materials and methods}

The Maracajaú area is located at the north of Rio Grande do Norte State (5'21'12S, 5'25'30'S and 35 $\left.14^{\circ} 30^{\circ} \mathrm{W}, 35^{\circ} 17^{\prime} 12^{\prime \prime} \mathrm{W}\right)$, Northeastern Brazil. In this area, there is an extensive reef formation, where an Environmental Protection Area was established in June 2001. During low tide, these reefs are generally at 0.5 to 1.0 meter depth from the surface and in some places at 1.5 meters depth. These formations are disposed in shallow waters and are nearly 10 $\mathrm{km}$ long and $4 \mathrm{~km}$ wide. These reefs are located $7 \mathrm{~km}$ offshore. The coast presents intense marine erosion and sharp cliffs that belong to the Barreiras Formation. Around $2 \mathrm{~km}$ from the coast, there is a channel 5 to 10 meters deep. Most of the bottom areas are covered with calcareous algae, except the channel, 
which is covered by seagrasses (Halodule whritii). The area is influenced by a small river (rio Maxaranguape). There are six coral species: Agaricia agaricites, Siderastrea stellata, Porites astreoides, Porites branneri, Favia gravida and Mussismilia hispida [8].

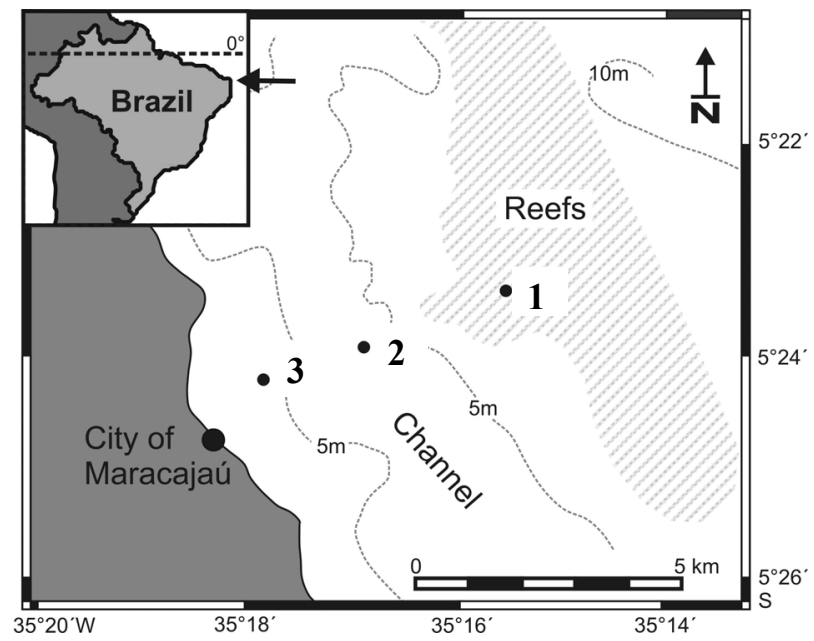

Figure 1: $\quad$ Studied area and stations.

Hydrology and plankton samples were collected from February to June/00, during diurnal low tide, at 3 fixed stations along a transect perpendicular to the coast of Maracajaú - RN (Figure 1). Station 1 was located over the reefs, station 2 on the channel that separates the reef area from the coast, and station 3 close to the coast. Local depth was measured with an ecobatimeter. Water transparence Secchi disc. Water for abiotic factors data were collected at surface with a Nansen bottle. The following variables were measured: temperature - digital thermometer; salinity (Mohr-Knudsen method); dissolved oxygen, Winkler method according to Strickland and Parsons [11]; pH - Hanna model 8417 pHmeter; nutrients $[12,13]$, and suspended material according to Melo et al. [14]. Chlorophyll-a concentrations were calculated by the spectrophotometric technique [15]. Phytoplankton primary productivity was measured by the ${ }^{14} \mathrm{C}$ method [16] and the phytoplankton assimilation tax was based in Vollenweider et al. [17]. Plankton sampling was performed with two nets (mouth of $30 \mathrm{~cm}$ diameter and $1 \mathrm{~m}$ length), one with $65 \mu \mathrm{m}$ mesh size (for microphytoplankton and microzooplankton) and the other $300 \mu \mathrm{m}$ mesh size (for macrozooplankton), fitted with a Hydrobios flowmeter. Five minutes horizontal surface hauls were made at each station. After collections, samples were immediately preserved in $4 \%$ neutral saline formaldehyde. In the laboratory, a $0.5 \mathrm{ml}$ sub-sample of the microphytoplankton and $1 \mathrm{ml}$ sub-sample of the microzooplankton were each placed in a Sedwick-Rafter chamber, identified and counted by species under a Zeiss compound microscope. A $4 \mathrm{ml}$ sub-sample of the macrozooplankton was placed in a Bogorov chamber, identified and counted by species under a Zeiss 
stereomicroscope. Triplicate sub-samples of each sample were counted. An ANOVA test was applied to verify differences among stations and months using the BIOSTAT program.

\section{Results}

Average hydrology data can be seen in Table 1. Local depth was minimum (1.4 $\mathrm{m}$ ) in Station 1 (over the reefs) and maximum $(7.8 \mathrm{~m})$ in Station 2. Warm water currents bath the region and the sea temperatures vary little throughout the year (minimum $26.5^{\circ} \mathrm{C}$ and maximum $29^{\circ} \mathrm{C}$ ). Water transparence varied from $1 \mathrm{~m}$ (May, Station 3) to 7.8 (February/00, Station 2). The $\mathrm{pH}$ was alkaline ( $>8)$. Dissolved oxygen varied from $4.26 \mathrm{ml} \mathrm{L}^{-1}$ (June/00, Station 1) to $6.16 \mathrm{ml} \mathrm{L}^{-1}$ (February/00, Station 1). Nitrite was always under $0.05 \mu \mathrm{mol} \mathrm{\textrm {L } ^ { - 1 }}$ and nitrate varied from $0.04 \mu \mathrm{mol} \mathrm{L}{ }^{-1}$ (June/00, Station 2) to $1.79 \mu \mathrm{mol} \mathrm{L}{ }^{-1}$ (February/00, Station 1). Minimum phosphate was $0.05 \mu \mathrm{mol} \mathrm{L}{ }^{-1}$ (February/00, Station 3), and maximum was $0.20 \mu \mathrm{mol} \mathrm{L} \mathrm{L}^{-1}$ (May/00, Station 3). Silicate varied from $2.38 \mu \mathrm{mol} \mathrm{L}{ }^{-1}$ (February, Station 2) to $10.98 \mu \mathrm{mol} \mathrm{L}{ }^{-1}$ (June/00, Station 3). Suspended material presented higher values in the rainy season and varied from $5 \mathrm{mg} \mathrm{L}^{-1}$ (February, Station 1) to $30 \mathrm{mg} \mathrm{L}^{-1}$ (May/00, Station 3).

Table 1: Abiotic and biotic parameters at Maracajaú reef system (RN, Brazil) in 2000 .

\begin{tabular}{|c|c|c|c|c|}
\hline \multirow[t]{2}{*}{ Parameters } & \multicolumn{2}{|c|}{ Dry season } & \multicolumn{2}{|c|}{ Rainy season } \\
\hline & Average & $\begin{array}{l}\text { Standard } \\
\text { Deviation }\end{array}$ & Average & $\begin{array}{c}\text { Standard } \\
\text { Deviation }\end{array}$ \\
\hline Depth (m) & 5.05 & 2.78 & 4.50 & 2.10 \\
\hline Transparence $(\mathrm{m})$ & 4.00 & 2.43 & 2.98 & 1.78 \\
\hline Temperature $\left({ }^{\circ} \mathrm{C}\right)$ & 28.97 & 0.08 & 27.22 & 0.79 \\
\hline Salinity (PSU) & 36.00 & 0.13 & 34.09 & 0.87 \\
\hline $\mathrm{pH}$ & 8.73 & 0.06 & 8.14 & 0.07 \\
\hline Dissolved oxygen $\left(\mathrm{ml} \cdot \mathrm{L}^{-1}\right)$ & 5.12 & 0.61 & 5.04 & 0.42 \\
\hline Dissolved oxygen saturation tax $(\%)$ & 116.25 & 13.89 & 110.17 & 10.44 \\
\hline Nitrite $\left(\mu \mathrm{mol} . \mathrm{L}^{-1}\right)$ & 0.02 & 0.02 & 0.01 & 0.02 \\
\hline Nitrate $\left(\mu \mathrm{mol} . \mathrm{L}^{-1}\right)$ & 0.78 & 0.51 & 0.57 & 0.42 \\
\hline Phosphate $\left(\mu \mathrm{mol} . \mathrm{L}^{-1}\right)$ & 0.08 & 0.02 & 0.16 & 0.04 \\
\hline Silicate $\left(\mu \mathrm{mol} . \mathrm{L}^{-1}\right)$ & 5.43 & 2.47 & 8.83 & 2.49 \\
\hline Suspended matter $\left(\mathrm{mg} . \mathrm{L}^{-1}\right)$ & 7.17 & 3.92 & 13.33 & 8.45 \\
\hline Chlorophyll a $\left(\mathrm{mg} \cdot \mathrm{m}^{-3}\right)$ & 2.18 & 2.32 & 3.98 & 4.08 \\
\hline Primary productivity $\left(\mathrm{mgC} \cdot \mathrm{m}^{-3} \cdot \mathrm{h}^{-1}\right)$ & 11.00 & 13.48 & 34.07 & 42.35 \\
\hline Assimilation tax $\left(\mathrm{mgC} \cdot \mathrm{m}^{-3} \cdot \mathrm{h}^{-1} /\right.$ Clora $\left.\cdot \mathrm{m}^{-3}\right)$ & 3.45 & 4.05 & 5.60 & 6.54 \\
\hline
\end{tabular}

Chlorophyll $a$ varied from $1.12 \mathrm{mg} \mathrm{m}^{-3}$ (February/2000, Station 3) to $9.3 \mathrm{mg}$ $\mathrm{m}^{-3}$ (May/2000, Station 3) with an average of $3.08 \mathrm{mg} \mathrm{m}^{-3}$. Higher phytoplankton biomass was registered during the rainy season. Lowest primary productivity occurred during the dry season over the reefs $\left(3.56 \mathrm{mgC} \mathrm{m}^{-3} \mathrm{~h}^{-1}\right.$, with an assimilation tax of $1.66 \mathrm{mgC} \mathrm{m}^{-3} \mathrm{~h}^{-1} / \mathrm{mg}$ clor $a \mathrm{~m}^{-3}$ ) and highest during the rainy 
season close to shore $\left(69.58 \mathrm{mgC} \mathrm{m}^{-3} \mathrm{~h}^{-1}\right.$, with an assimilation tax of $7.48 \mathrm{mgC}$ $\mathrm{m}^{-3} \mathrm{~h}^{-1} / \mathrm{mg}$ clor $a \mathrm{~m}^{-3}$ ). In general, high phytoplankton productivity in coastal areas and low productivity offshore are characteristic features of this area.

Plankton biomass in the microzooplankton fraction varied from $45.19 \mathrm{mg} \mathrm{m}^{-3}$ (Station 1, June/2000) to $316.45 \mathrm{mg} \mathrm{m}^{-3}$ (Station 1, March/2000). In the macrozooplankton fraction the biomass varied from $9.33 \mathrm{mg} \mathrm{m}^{-3}$ (Station 1, March/2000) to $43.16 \mathrm{mg} \mathrm{m}^{-3}$ (Station 1, February/2000). Average values were $117.01 \mathrm{mg} \mathrm{m}^{-3}$ (microzooplankton) and $15.71 \mathrm{mg} \mathrm{m}^{-3}$ (macrozooplankton).

Phytoplankton was present with 136 taxa. Diatoms were the most diverse (102 species), being more abundant in decreasing order: Chaetoceros curvisetus, Pseudosolenia calcaravis, Bleackeleya notata, Isthmia enervis, Prosbocia alata, Fragilaria capucina, Rhabdonema adriaticum, Podocystis adriatica, Bacillaria paxillifera, Asterionellopsis glacialis, Biddulphia biddulphiana, Chaetoceros lorenzianus and Guinardia striata. Dinoflagellates were present with 18 species, Ceratium furca was the most abundant and frequent. Phytoplankton diversity and

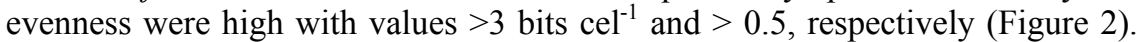
Minimum phytoplankton density was $2,067.10^{-3}$ cell $1^{-1}$ (Station 2, March/2000)

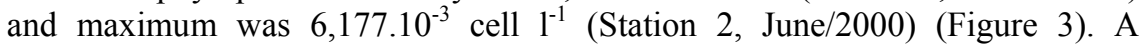
seasonal pattern was observed with the highest numbers occurring through the summer rainy season (February).

Zooplankton was represented by 61 taxa, with 50 taxa in the microzooplankton and 40 in macrozooplankton fractions, and 20 taxa common to both. Copepoda was the taxa with greatest diversity (23 species). Holoplankton dominated $(65 \%)$ in the microzooplankton while in the macrozooplankton both holoplankton and meroplankton were equally distributed. Microzooplankton species diversity and evenness presented most values varying from 2 to 3 bits ind $^{-1}$ and $>0.5$, respectively (Fig. 2). The macrozooplankton species diversity was in generally low $\left(<2\right.$ bits ind $\left.^{-1}\right)$ due the dominance between few copepods species and other crustacean, mainly brachyuran zoeae; evenness was $>0.5$ (Figure 2).

The micro- and macrozooplankton followed a seasonal pattern, with the highest numbers occurring through the summer rainy season (February). A high density was found for the microzooplankton, which varied from 1,917 ind $\mathrm{m}^{-3}$ (Station 3, June) to 47,620 ind $\mathrm{m}^{-3}$ (Station 2, February) (Figure 3). Microzooplankton abundances were usually greatest at Station 3 and lowest at Station 2. An exception to this trend occurred in February/2000, when Station 2 had markedly higher abundance than the other stations. The contribution of the inshore zooplankton community to these peaks is indicated by the abundances of the copepods (Parvocalanus crassirostris, Euterpina acutifrons, Oithona hebes and their nauplii) and bivalve larvae. The macrozooplankton presented low densities varying from 92.4 ind $\mathrm{m}^{-3}$ (Station 3, June) to 1,617 ind $\mathrm{m}^{-3}$ (Station 1, February) (Figure 3). Most individual taxa showed a seasonal cycle of abundance similar to that of total macrozooplankton, although meroplankton (mainly brachyuran zoeae) dominated Station 1 during all months and in June at all stations. ANOVA test showed significant differences in density among stations $(p<0.05)$ and the months of February and June $(p<0.05)$ in phytoplankton, micro- and macrozooplankton. 


\section{PHYTOPLANKTON}

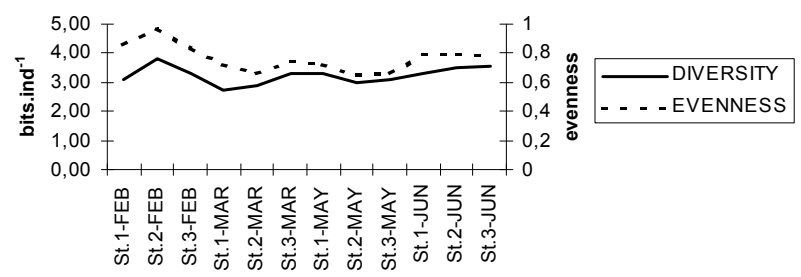

STATIONS

\section{MICROZOOPLANKTON}

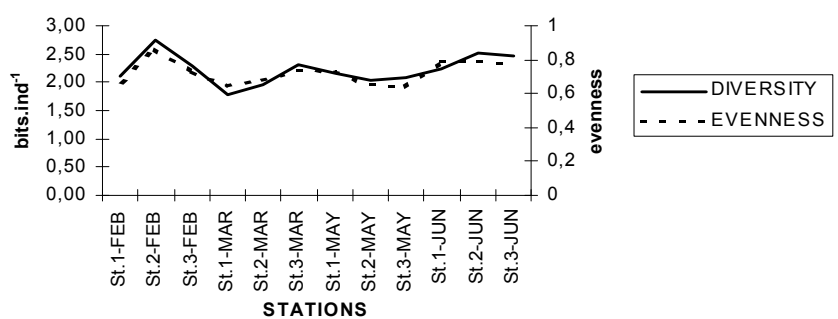

\section{MACROZOOPLANKTON}

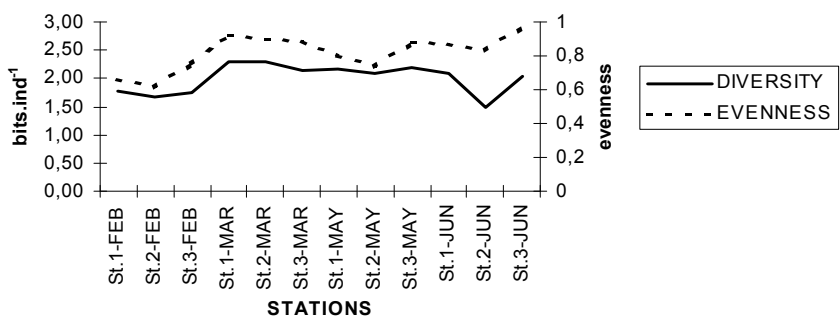

Figure 2: Species diversity and evenness of the phytoplankton, microzooplankton and macrozooplankton at Maracajaú reef ecosystem in Brazil.

We observed that the Maracajaú reefs and adjacent ecosystems suffer a large variety of human impacts on diverse spatial and temporal scales. Among the main problems are the anchoring and traffic of small private motor boats on the reef, and the leakage of oils and fuels. Scuba diving, artisan and sports fishery are locally important activities, which are now being regulated in the context of the management of the Maracajaú Marine Protected Area. Local people have reported the occurrence of oil spills by tankers and large freighters passing 

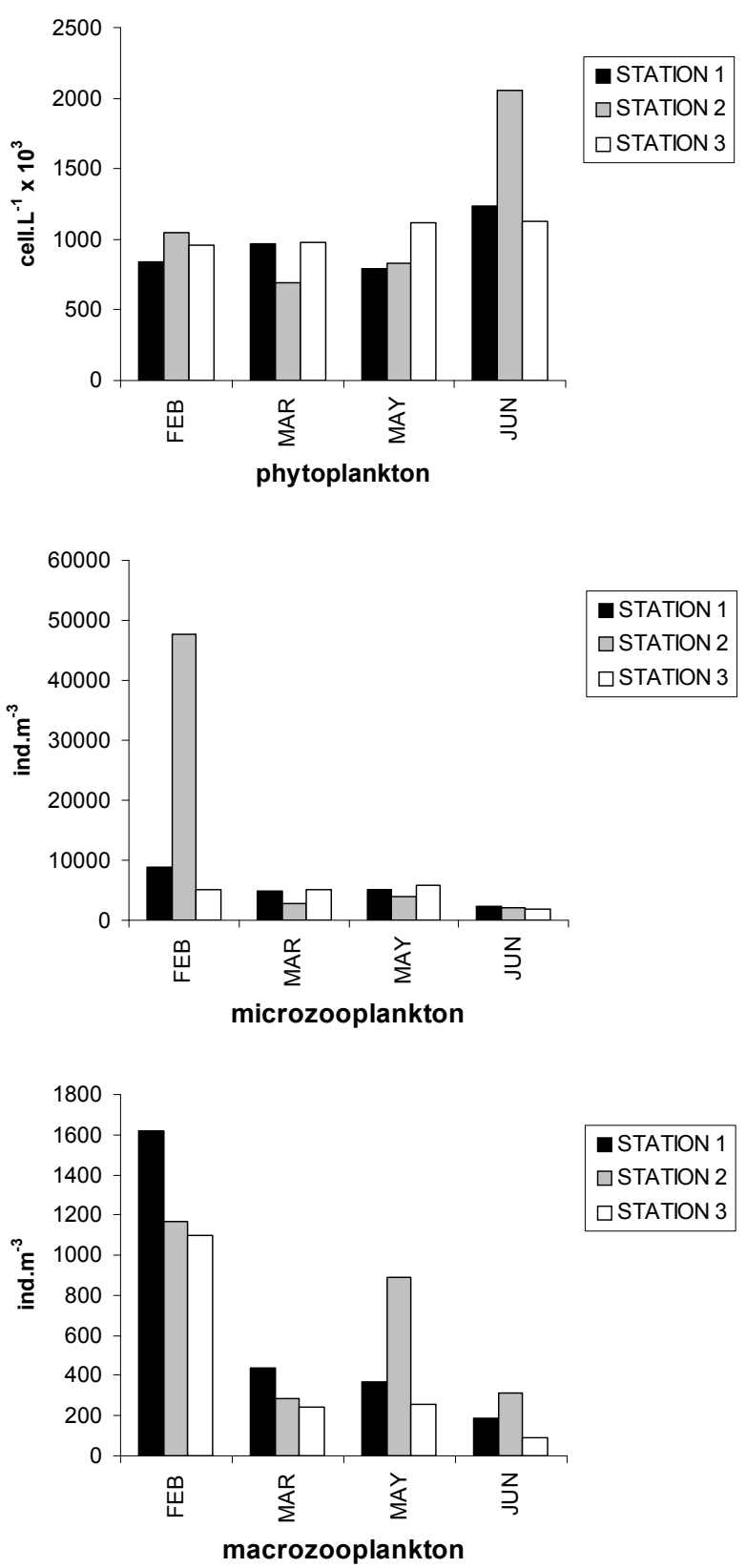

Figure 3: Density of the phytoplankton, microzooplankton and macrozooplankton at Maracajaú reef ecosystem in Brazil. 
offshore. The impressive amount of untreated domestic sewage from Maracajaú and adjacent cities and the illegal destruction of estuarine mangroves for landfills and urbanization is a constant threat to the Maracajaú reef system.

A dendrogram based on all plankton samples presented 5 groups (Figure 4): 1) A group composed by oceanic species; 2) A group from coastal areas - the neritic; 3) A mixture of neritic and oceanic species; 4) Typical reef zooplankton both holo- and meroplankton with higher species number; and, 5) the estuarine group brought by the estuarine flux.

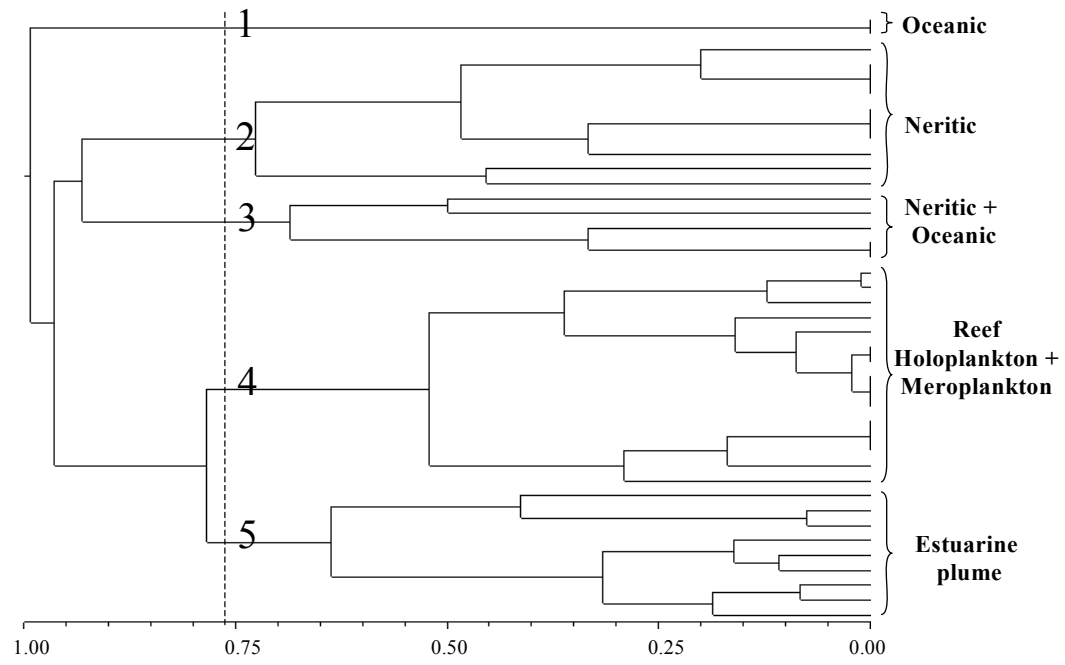

Figure 4: Dendrogram based on plankton samples from Maracajaú reef ecosystem, Brazil.

\section{Discussion}

The plankton is an important component of the reef ecosystem as can be seen in conspicuous abundance of planktivorous animals in many reef communities. Thus, plankton represents a major source of food to the coral reef community and it is important to know whether it is entirely derived from other areas or is in part a member of the reef community. Among the reef animals feeding on plankton, there are numerous planktonic and benthic filtering invertebrates, benthic sediment feeders (including corals), abundant populations of planktonivorous fishes, and all fish larvae [6]. Nevertheless, the reef zooplankton in northeastern Brazil has been less studied than the plankton of open oceanic waters. Several plankton abundance studies all over the world have shown that coral reefs remove 20 to $80 \%$ of the plankton from water passing over reef crests and flats [18-21]. If these filtration efficiencies are realistic, the coral reef may be regarded as a huge sieve capable of differential filtration, and thus their study in Brazil is of great importance.

Our sampling period in the Maracajaú reef area spanned successive months from the rainy to dry season, the rainfall being an important physical regulator of 
the plankton dynamics in the Maracajaú reef. The summer of 2000 was characterized by high rainfall $(>250 \mathrm{~mm})$, and considerable riverine discharge (seen by the visible turbid plume of the Maxaranguape River). In contrast, the dry season brought very little rainfall $(<50 \mathrm{~mm})$, and was characterized by some intrusion from the oligotrophic South Equatorial Current.

The broad phytoplankton biomass patterns we observed were different to those described by Sassi et al. [22] to the reef area of Ponta de Pedras (Paraíba State), south to the studied area, where chlorophyll $a$ were higher in the rainy season. In our study, phytoplankton biomass in terms of chlorophyll $a$ was higher at the dry season. However, higher cell counts values were registered in the rainy season. For the zooplankton the total net plankton biomass increased in the rainy season as a result of an increase in numbers of nauplii and juvenile copepods, mainly Oithona sp. Similar patterns were found to the reef area of Tamandaré in the south of Pernambuco State, Northeastern Brazil [23, 24]. Our data suggest a dynamic relationship between the plankton communities characteristic of inshore water trapped by the coastal boundary layer and more offshore plankton communities. The extent of the inshore plankton community changes under the influence of both meteorological and hydrographic forcing events, primarily wind speed and direction, and terrestrial run-off.

\section{References}

[1] New, T. R. (1995). An Introduction to Invertebrate Conservation Biology. Oxford University Press, Oxford, 194p.

[2] Kohn, A. J. (1997). Why are coral reef communities so diverse? In: Ormond RFG Gage JD, Angel JD (Eds.), Marine Biodiversity, Patterns and Processes. Cambridge University Press, Cambridge (UK), p. 201-215.

[3] Laborel, J. (1965). Note préliminaire sur lês récifs de grés et récifs de coraux dans lê Nord-Est brésilien. Rec. Trav. Stat. Mar. Endoume, 37(53): 341-344.

[4] Emery, A. R. (1968). A preliminary observation on coral reef plankton. Limnol. Oceanogr., 13:293-303.

[5] Sale, M. C.; McWilliam, P. S. \& Anderson, D. T. (1976). Composition of the near reef zooplankton at Heron reef. Mar. Biol., 34:596.

[6] Sorokin, Y. I. (1990). Plankton in the reef ecosystems. In: Dubinsky, Z. (Ed.), Ecosystems of the World 25: Coral Reefs. Elsevier, Amsterdam. p. 291-327.

[7] Laborel, J. (1967). Les peuplements de Madréporaires des côtes tropicales du Brésil. Univ. Aix-Marseille, França, Thése. Fac. Sci. 313p.

[8] Mayal, E.; Feitosa, F. A. N.; Neumann-Leitão, S.; Fernandes, M. B.; Ramos, B.; Lima, E. \& Almeida, A. (2001) Coral from the reef table type of Maracajaú - RN - Brazil. In: IX Congreso Latinoamericano Sobre Ciencias del Mar, San Andrés. Universidade Nacional de Colombia, 2001.

[9] Melo, N. F.; Neumann-Leitão, S.; Silva, T. A; Schwamborn, R. \& Gusmão, L. M. O. (2002). Zooplankton from Maracajaú reef area, Rio Grande do Norte (Brazil). Trop. Oceanogr., 29. 
[10] Feitosa, C.V.; Pimenta, D. A. S.; Araújo, M. E. (2003). Ictiofauna recifal dos parrachos de Maracajaú (RN): inventário, estrutura da comunidade e interferência antrópica. Arq. Cienc. Mar, 35:1-17.

[11] Strickland, J.D.H.; Parsons, T.R. (1965). A manual of seawater analysis. Bull. Fish. Res. Board Can. 125:1-205.

[12] Strickland, J.D.H.; Parsons, T.R. (1972). A practical handbook of seawater analysis. Bulletin Fisheries Research Board of Canada 167:207-211.

[13] Grasshoff, K.; Ehrhardt, M.; Kremling, K. (1983). Methods of Seawater Analysis. Verlag Chemie, 2nd edition, 419p.

[14] Melo, V.; Summerhayes, C.D.; Toner, L.G. (1975). Metodologia para estudos do material em suspensão na água do mar. Bol. Téc. Petrobrás 18(314):115-127.

[15] Parsons, T.R.A.; Strickland, J.D.H. (1963). Discussion of the spectrophotometric determination of the marine plant pigments, with revised equations for ascertaining chlorophylls and carotenoids. Journal of Marine Research 21(31):155-163.

[16] Steemann-Nielsen, E. (1952). The use of radioactive carbon $\left({ }^{14} \mathrm{C}\right)$ for measuring organic production in the sea. J. Conseil Intern. Expl. Mer 18(2):117-140.

[17] Vollenweider, R.A.; Talling, J.F.; Westlake, D.F. (1974). A manual in method for measuring primary production in aquatic environments, including a chapter on bacteria. International Biological Program Handbook, Oxford, 2nd ed. 225p

[18] Tranter, D. J. \& George, J. (1972). Zooplankton abundance at Kavaratti and Kalpeni Atolls in the Laccadives. Proc. Synp. On Coral Reefs. Mar. Biol. Assoc., India, pp. 239-256.

[19] Glynn, P. W. (1973). Ecology of Caribbean coral reef: plankton community with evidence for depletion. Mar. Biol., 22:1-23.

[20] Johanes, R. E. \& Geber, R. P. (1974). Import and export by Eniwetok reef Community. Proc. $2^{\text {nd }}$. Int. Coral Reef Symp., Brisbane, 1: 97-104, 1974.

[21] Lefreve, M. (1985). Spatial variability of zooplanktonic populations in the lagoons of a high island (Moorea, French Polynesia). Proc. $5^{\text {th }}$ int. Cor. Reef Symp., Tahiti, 6:39-45.

[22] Sassi, R.; Veloso, T. M. G.; Melo, G. N. \& Moura, G. F. (1991). Variações diurnas do fitoplâncton e de parâmetros hidrológicos em recifes costeiros do Nordeste do Brasil. Encontro Brasileiro de Plâncton, 5, Recife, 1990. Ed. Universitária. p. 61-96.

[23] Nascimento-Vieira, D. A. (2000). Macrozooplâncton recifal da baía de Tamandaré, Pernambuco - Brasil. PhD thesis. Federal University of Pernambuco. Dept. Oceanography, Recife. 107 p.

[24] Porto Neto, F. F.; Neumann-Leitão, S.; Nascimento-Vieira, D. A.; Silva, A.

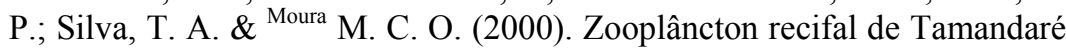
- PE (Brasil) e a influência dos manguezais na sua biodiversidade e biomassa. Mangrove 2000, Sustainable Use of Estuaries and Mangroves: Challenges and Prospects. Recife, CDRom. 10p. 